\title{
Study on the Traditional Ceremonial Miao Dance Style in Western Hunan
}

\author{
Xiaoya Long ${ }^{1}$ \\ ${ }^{1}$ Jishou University, Jishou, Hunan, 416000
}

Keywords: Miao people in Western Hunan; traditional ritual dance; types

\begin{abstract}
Miao traditional ritual dance in Xiangxi usually takes place during festivals or festivals. This paper tries to make a preliminary inquiry into the traditional types of ceremonial dances from the functions of sacrificial offerings. It can be roughly divided into three types, ancestor worship, nature worship, and reproductive worship. In the process of worship, sometimes there are various dances interspersed with one another, and there is also a pattern of continuous repetition. Therefore, the exploration of the traditional ritual dance style of the Miao people in Xiangxi still requires long-term and more in-depth excavations. Differentiating these types of dance movements, formations, venues, etc., helps to understand the style of various types of dance charm.
\end{abstract}

\section{Introduction}

Every ethnic group has its own ethnic and folk culture. The various cultural phenomena embodied in these ethnic and folk cultures, whether material or spiritual, reflect the soul of the nation in all aspects of production and life-for a certain A kind of cultural psychological identity.

When we observe and study the cultural and cultural products of the Miao people in Xiangxi, such as dress, silverware, printing and dyeing, and daily necessities, it is easy to find that the epic, migration, and folktale of Miao nationality are traced in these objects that are both works of art and daily necessities. At the same time, some non-material cultural heritage such as ballads, music, and dance are also recorded in the form of hand-to-hand or clothing, painting, and writing, reflecting the way of thinking and spiritual sustenance of the Miao people in Xiangxi.

Most of the dances of the Miao people in western Hunan have the original meaning of worship. In festivals, rituals, and rituals, we can often see different forms of dance, such as "Dragon Dance" and "Fragrance Dance". Wait. The specific details of these traditional ceremonial dance types are broadly divided into the following three categories:

\section{Dance of Ancestral Worship of Singing Songs}

Among the traditional ritual dance types of the Miao people, the most representative is the dance that has spread from the ancestral worship consciousness to its present stage of development. This type of dance can be found in books such as "The Miao Ancient Song" and the Miao "Ancient Dialect". Whether it is the ritual rituals of the dying of the vertebral cows or the chanting of wishes, or the wood-drum, the copper-inspired, and the deaf-dance, the Miao people have demonstrated their infinite dedication to the ancient wisdom and power of the ancestors.

Miao ancestors are encouraged by the Maple Wood, which is the ancestor of "Maple Mama". After the wooden drums are hollowed, the two ends are covered with skins. After the development into the bronze drums, due to the high cost of copper drums, mostly used by nobles, as well as historical and environmental factors in the process of inheritance, the most common still is wooden drums. Wooden drums are in various forms. They dance with drums, and they are inspired by New Year, Luniu, Solitaire, and Reunion. Inspired by the "Huagu", the encouragement in Xiangxi region is typical. In the process of "meal eating filthy" ("drums combined with drums"), the drum became a ritual for worshiping gods and drums, although the encouragement of the tourist region is now more "inspired". Development is more of the contents of entertainment. From the choreography point of view, modern choreographic techniques have been incorporated. However, the encouragement in remote areas is still held on specific festivals. We can even see "butterfly 
mothers" on some drums. The portrait of ".

The main part of the break dance is the ancestor of the Hmong ancestor, the aunt and father-in-law. In the process of wishing for victory, the shamans wear masks to show different characters, hold hand tools, stage the vanguard, move mountains, and move the land. During the sacrificial ceremony, the ancestors' tablets were called "fruits" in the Hmong language. Every time the sacrificial young generations worshiped the ancestors' souls with good wine and good spirits, they blew three passions on the wine and meat, which meant that the ancestors should enjoy them. Break dance rituals mainly solve problems that are difficult to solve in people's lives. They pray for God's blessing in order to be disease-free and disaster-free. Among them, the classification of skull masks is a good interpretation of the functional and sacrificial nature of the dance, and the props on the hands are also responsible for their duties, which increases the mystery and makes the dance full of dramatic colors.

In the rituals of asking ghosts (ancestors) and sending ghosts (ancestors), the form of daring cymbals in the form of drums or break dances is not carried out in a single manner. It is often used in the same ceremonies, such as the combination of vertebrae and drums. Performance rituals such as performing drums or reunion drums are all done at one go. Their purpose is to pray for their ancestors to protect and protect the people. At the same time, in the process of these rituals, it is also a form of passing on the ancestral merits from generation to generation. Therefore, although there are no written records for later generations to pursue, the dripping of these ancestral worship rituals is not the living fossil that people pass on the ancestor's spirit and wisdom from generation to generation.

\section{Pray for Peaceful Harmony of Nature Worship Type Dance}

In addition to cultivating their ancestors, the Miao people have a spiritual sense of worship for all nature. They believe that both natural and natural phenomena can be protected by pious worship and prayers. For example, the dragon dance and the fragrant dance belong to the Miao people's worship ceremony for natural gods. Dances often performed.

Most of the performances of Solitaires performed during the ceremonies of the lunar calendar in February and October. In the stories passed down by the Hmong ancestors, we can almost know that the deified image of "Dragon" symbolizes thunder, rain, and flooding. All natural phenomena are controlled by it. When it is rainy, it is dry and rainy. Therefore, dedication to the "Dragon" God has become an indispensable ritual activity for the daily life of the Miao ethnic group. In order to prevent the "Dragon" from being displeased, women who jumped and danced dragons and dances must pick beautiful women's costumes to imitate "dragons" with handkerchiefs or umbrellas. From a distance, they look like "dragons" from the riverside, streams, and wells. To the "Dragon Church" at home, the entire process of ritual dance is sacred and beautiful. In the process of harvesting winds in the fields, we discovered that it was a long way before the Hmong Women's Women's Solitaire team packed their way into the home. The process was rather arduous. It was muddy uphill and muddy and did not want to be mixed in the team. Into other miscellaneous people and so on, in a sense, undermined the sacred feeling of the ceremony.

The fragrant dancing is most common in the Suixi area of western Hunan, and is held every October in the Lunar Calendar. This is also a product of farming culture. Since there are crops, there will inevitably be "God of Grains," and it is the "grains of God" that govern the growth of the crops. At the time of the sacrifice, led by Miao Laosi, starting from the Shennong Temple, the Miao people held props or circling around, or entered various households, to show the "grass god" the joy of harvest, and pray for the good weather in the coming year to exempt the disaster. The dance of fragrant dancing mainly consisted of formation changes. Changes in formations such as rounding circles and marking eight-character circles reflected the ups and downs of the farmer's field laps. The dancing movements were heavy and steady, and there were few big jumps and rotations.

Dances of the natural worship type are generally held at specific Miao ethnic festivals. Their role is not only sacrificial, but also has the effect of entertaining people to entertain the gods. There are also some other types of dances that show people the labor scene. For example, monkeys in Xiangxi 
encouraged the monkeys to steal corn when they imitated the bumper harvest. They were humorous and humorous. They also told the world the philosophy. From the dance of nature worship, we can find the original worship of the Miao farming culture, and also inherit and preserve the non-material spiritual products of the farming culture.

\section{Free and Romantic Type of Reproductive Worship Dance}

The Miao people advocate free love and have an advanced marriage system. Among them, the dances that reflect the Miao people's free love are reed dances and moon dances. Some villages still retain totems that symbolize male genital organs. For example, there are totem poles resembling male roots in the jumping lunar plaza of Shanjiang Furnace Pingmiao District. Mausoleum that symbolizes the woman's touch when she meets. Although these totem artifacts have gradually disappeared from the city because of difficulties, we can still find the legacy of reproductive worship in remote villages.

The reed dance or the moon-jumping is usually performed with songs, dances, and music. The young men and women use the form of playing reeds and dancers, or freely seek songs and dances to seek for a partner. In the process, young men and women singing and melodious music, or dancing movements to convey feelings and expressions, it is easier to find their own people. The "jumping month" also has a dance under the moon. Some people leave the field halfway through the ceremony, and they are determined to find someone who loves and chooses, and they choose to be together. The rest of the men, women, and children dance around the fire, and they also have inspired performances.

Since dances such as reed dance and moon-jumping have obvious courtship consciousness, usually require specific occasions and specific artifacts, and because they advocate the concept of free love and prosperity, these dances in the consciousness of primordial reproductive worship are circulated and become men and women. A traditional ritual dance with the meaning of free and romantic reproductive worship, pairing and mutual love.

These traditional ritual dance types popular in the Xiangxi region are preserved from the rituals of the original worship of the Miao people. They are closely related to natural phenomena, farming life, marriage warfare, etc., pay attention to the formation and venue, and also have strict requirements on the use of props. It can thus be seen that the function of traditional ritual dances has a clear awareness of ancestors, nature, and reproductive worship. The dance in the Miao region in Xiangxi cannot be distinguished from religion-witches. To understand the dance culture of the Miao nationality in Xiangxi, we must first understand the origin of the Miao ethnic dance in Xiangxi and understand their specific types, so as to show the style of the Miao dance in Xiangxi.

\section{Acknowledgements}

Project Number: Grant of Scientific Research Project of Hunan Provincial Department of Education (No. 17C1319)

\section{References}

[1] Long Qinghe. "Western Miao Xinjiang" [M]. Hong Kong: Tianma Publishing Co., Ltd., 2007

[2] He Xingliang. Totem and Chinese culture [M]. Jiangsu: Jiangsu People's Publishing House, 2008 (1).

[3] Yang Changjia, Gong Renjun. Suixi folk pick up shellfish [M]. Beijing: Central University for Nationalities Press, 2009(1).

[4] Luo Zhufeng, Chen Zemin. Introduction to Religion [M]. Shanghai: East China Normal University Press, 1991 (December).

[5] Zhang Ziwei. Xiangxi culture mystery [M]. Hunan: Hunan Normal University, 1991 (12). 